\title{
EREBEA
}

Revista de Humanidades

y Ciencias Sociales

Núm. 6 (2016), pp. 65-86

ISSN: 0214-0691

\section{El mito británico de la Peninsular WaR}

\author{
Manuel Moreno Alonso \\ Universidad de Sevilla
}

RESUMEN

Este artículo aclara el concepto de la denominada Peninsular War, poniendo de manifiesto la parcial versión británica del mismo a lo largo de los siglos. Un recorrido historiográfico riguroso demuestra que la guerra, ejemplo de resistencia espańola y de inactividad británica, dejó sin embargo, una versión manipulada y desvirtuada de los hechos que minimizaban el esfuerzo español y maximizaban los logros británicos. Se analizan datos interesantes de los ecos de tal guerra en Gran Bretaña, desde la acuñación de la expresión por Robert Southey en 1823 a su rastro en periódicos, representaciones teatrales, novelas, relatos de aventuras y viajes. Así mismo se presentan fuentes españolas antes ignoradas que recuperan voces alternativas para complementar y rechazar la representación británica, tradicionalmente entendida en clave de gesta heroica.

\section{Palabras Clave}

Peninsular War; guerra antinapoleónica; Wellington; ejército británico.

Fecha de recepción: 17 de nov. de 2016 Fecha de aceptación: 30 de nov. de 2016

\section{Abstract}

This article clarifies the concept of the so-called Peninsular War, exposing the partial British version used along the centuries. A rigorous historiographic approach proves that the war, an example of Spanish resistance and Bristish inactivity left a manipulated and distorted view of the real facts, minimizing Spanish efforts and maximizing British victories. Interesting facts about the echoes of that war in Great Britain are provided, from Robert Southey's first use of the expression in 1823 to traces in journals, theatrical representations, novels, adventure stories, and travel accounts. Spanish sources that have been historically ignored are taken into account and prove alternative voices to complement and reject the British representation, traditionally understood as a heroic deed.

\section{KeYwords}

Peninsular War; antinapoleonic war; Wellington; Bristish army. 

La guerra contra Napoleón en España (1808-1814), que afectó a Portugal desde 1807, es una lucha de especial significación en todos los países implicados, que los británicos han llamado Peninsular War, y sus historiadores han explicado como una guerra llevada a cabo al margen de sus aliados, como si apenas hubiera tenido que ver con la de estos. Hecho que obedece, sin duda, a que ambos Estados peninsulares se habían convertido en dos subpotencias frente a los dos gigantes europeos, Francia e Inglaterra, que luchaban por el control económico y político de Europa. Pero esto no quiere decir que fuera una guerra periférica, de importancia secundaria por tratarse de un frente alejado de París o Londres. Muy por el contrario, fue en España donde se decidió el destino de Napoleón en aquella brutal guerra de resistencia y desgaste que terminó por arruinar a la Península. Como muy expresivamente dijo el general francés Sarrazin -que en 1810 se pasó a los ingleses y en 1814 fue autor de una de las primeras Histoire de la guerre d'Espagne et Portugal de 1807 à 1814 - "la guerra en España tuvo en suspenso a todos los espíritus"'.

Sin embargo, realizada y contada después la guerra como cosa propia, la versión británica que ha prevalecido se ha construido al margen de la guerra sostenida por España, con lo cual aquélla pierde buena parte de su significación si la analizamos desde un punto de vista historiográfico riguroso, teniendo en cuenta la magnitud y el significado de la lucha en la Península. Pues durante seis largos ańos ésta se convirtió en el único escenario continental donde de forma ininterrumpida se materializó el enfrentamiento con Napoleón a causa de la sorprendente resistencia de España y a pesar de la prolongada inactividad en ésta por parte británica, resultante del fracaso de la cooperación entre ingleses y españoles que pronto habría de surgir entre los propios aliados. Lo que llevó al famoso historiador militar británico Charles Napier a decir que Wellington "había peleado por España, y en España, y nunca con Espańa"2.

Desde el punto de vista historiográfico actual no cabe la menor duda de que esta guerra presenta un interés bastante menor si privilegiamos en su conocimiento la parte por el todo, en el caso de que pueda admitirse que la visión particular del

1 "La guerre d'Espagne tenait en suspense tous les esprits", en Mémoires du Général Sarazin, écrites par lui même depuis 1770 jus'qu' en 1848. Bruselas: Vancaulaert, 1848, p. 244.

2 José Canga Arguelles, Observaciones sobre el tomo segundo de la Historia de la guerra de España que escribió en inglés el teniente coronel Napier, Londres: D. M. Calero, 1830, p. 84. 
conflicto, en este caso la lucha británica por sí sola, pueda explicarse al margen de la totalidad. Es decir, que difícilmente aquélla puede entenderse si se desprende de la lucha a muerte que los españoles en su conjunto -ejército y pueblosostuvieron por su independencia en una guerra plenamente revolucionaria por su contenido político, ideológico y social.

Que en ello ha consistido la versión tradicional que los ingleses han dado de "su" guerra en la Península, despreciando tantos y tantos aspectos fundamentales para su comprensión, mucho de los cuales tienen, incluso, una significación mucho más relevante desde el punto de vista histórico. De donde la necesidad, por un lado, de señalar las pautas de lo que fue la contribución británica a la guerra antinapoleónica en España y, por otro, analizar los fundamentos de su interpretación tradicional, tan necesitados como están de una revisión profunda.

Ciertamente cada uno de los contendientes combatió contra los ejércitos napoleónicos a su modo y, con bastante frecuencia, de forma contrapuesta, sin tener en cuenta a sus aliados. Lo que hizo que, al final, estos hicieran su propia guerra, que luego sus historiadores contaron a su modo. Dentro de este contexto lo vio muy bien un militar francés a comienzos del II Imperio, al señalar con gran agudeza que el ejército de Napoleón tuvo que luchar contra tres naciones: la española, "perseverante en su odio"; la portuguesa, "de parecido comportamiento", y la inglesa, "fría, hábil calculadora de las posibilidades de éxitos y sabiendo merecerlos por bravura"

El relato británico de esta guerra tampoco ha valorado en su justa medida que Gran Bretaña vio en la sublevación española una oportunidad excepcional para combatir a Napoleón, cuyos ejércitos se encontraban esparcidos por todas las partes de Europa sin poder abandonarse a sus intereses sin grave daño. Lo que explica que el levantamiento de los espańoles provocara tal entusiasmo que hasta en los teatros de la capital inglesa se representó entre otras muchas una pieza de teatro con el título de The Spanish Patriots, or a Nation in Arms (1808). Incluso los mismos periódicos lo presentaron con rara unanimidad como la "última oportunidad" que se ofrecía para poner coto a la prolongada marea de victorias francesas.

Igualmente parece haberse desdibujado la excepcional oleada de hispanofilia que conmovió al Reino Unido como no se recordaba nunca. Lo que dio lugar a que nadie pusiera en duda que la entrada de España en la lucha iba a suponer el debilitamiento del enemigo común al contar con una plataforma estratégica desde la que actuar, que ofrecía un teatro de operaciones mucho más difícil de dominar para los franceses que las llanuras de Alemania o los Países Bajos. Razón por la cual no son raros los testimonios británicos que hablan, incluso, de que la "salvación de España" no dependería solo de sus esfuerzos, "ni tampoco de nuestra

3 Antoine Laurent Apollinaire Fée, Souvenirs de la guerre d'Espagne: dite de l'indépendance, 1809-1813. París: Berger-Levrault, 1856, p. 294. 
ayuda por grande que sea", sino que era preciso conectar la guerra en España con movimientos hostiles en otras regiones de Europa.

No obstante lo cual, al final, lo que ha prevalecido ha sido una versión oficial de aquella guerra que, prescindiendo de esta realidad, ha desvirtuado la historia, minimizando el esfuerzo peninsular a favor de la victoria final, que muchos británicos siguen creyendo haber sido exclusiva de ellos. Olvidando el hecho de que la Península sufrió extraordinariamente el peso del inmenso poder de Napoleón, la versión británica de "su" guerra es, además, tan negativa de sus aliados españoles que en muchos casos sus explicaciones hasta parecen tener mucho más que ver con argumentos procedentes de los prejuicios de la "leyenda negra” que de la más elemental explicación histórica. Pues fueron demasiadas las ocasiones en las que los británicos vieron solamente lo que quisieron ver. Con lo cual se distorsiona la realidad de un conflicto mucho más complejo en el que lo mismo los sucesos que la forma de narrarlos a lo largo del tiempo precisan de otros elementos para su mejor comprensión y esclarecimiento.

También parece haber desaparecido de la memoria el impacto que en su tiempo ejerció en el Reino Unido la actitud de resistencia sin igual de "toda la nación española” frente al ataque napoleónico, un hecho que conmovió al mundo y que no tenía precedentes en el continente. Así lo entendió en Inglaterra el famoso radical William Cobbett, quien, después de haber leído las proclamas de aquellos "hombres resueltos", señaló que por fin había surgido un "espíritu general de resistencia" contra Francia. "Esta es la única oportunidad justa que se ha ofrecido para detener el progreso de Napoleón. Es la única causa a la que el pueblo de Inglaterra ha deseado el éxito con todo su corazón", dijón .

Todo lo cual dio lugar a una lucha conjunta de extraordinaria significación para ambos países que vinculó a las dos naciones de forma muy especial. Hasta el punto de constituir el comienzo de la implicación británica en los asuntos españoles, que habría de extenderse hasta la consolidación definitiva del régimen liberal en España en 1840, si bien desde el comienzo de la guerra peninsular no volverá a haber entre Inglaterra y España un solo incidente serio de rivalidad militar. A lo que hay que añadir también en ambos países el efecto de una guerra patriótica y nacional como aquélla con tan elevado componente ideológico y de opinión henchido de consecuencias.

La guerra comenzó en 1808, un año que en el caso de España constituye un punto de referencia fundamental en su historia (equivalente a lo que para Francia pudo ser 1789) que, lejos de ser una fecha más en las guerras napoleónicas, propició el desencadenamiento de una experiencia revolucionaria de proporciones desconocidas que los nuevos aliados difícilmente pudieron calibrar. Pues para los tories entonces en el poder la revolución la representaba el jacobinismo de

4 “Spanish Revolution”, en Cobbett's Weekly Political Register, vol. 14 (1808), p. 9. 
Bonaparte, por lo que era necesario sostener los derechos de las monarquías de Europa.

De esta forma, lejos de atisbar el movimiento revolucionario que acababa de desencadenarse en Espańa no solo en el orden social sino en el político (la constitución de hecho de un poder que solo de derecho implicaba el respecto a los fundamentos jurídicos del orden absolutista), los británicos siempre pensaron que, en su orden de prioridades, la guerra debía concentrar los esfuerzos de los españoles, y que las reformas tenían que centrarse en el terreno militar. Con lo cual los nuevos aliados difícilmente pudieron comprender buena parte de las vicisitudes de una guerra revolucionaria que como tal era tan diferente de los enfrentamientos convencionales. De donde las grandes limitaciones de la visión de "su" guerra en la Península.

Doscientos ańos después, sin embargo, el análisis detallado de una guerra como aquélla ofrece innumerables aspectos que no pueden seguir siendo tratados desde el punto de vista tradicional, y mucho menos explicados al margen de aquella lucha conjunta que, en lo que concierne a la Península, presenta rasgos fundamentales y desconocidos para su comprensión global. Aun cuando, en una permanente crisis de alianza con los españoles, los ingleses en su lucha contra las tropas napoleónicas lucharon como en una guerra dentro de otra.

El hecho es tanto más destacado cuanto que esta guerra ocupa un lugar fundamental en la historia y en la historiografía tanto de España como de Inglaterra. Con la particularidad de que, por espacio de seis ańos, dos naciones que tradicionalmente habían sido rivales, lucharon contra un mismo enemigo dentro de una alianza muy difícil. Un autor francés ha sostenido que los españoles adoptaron con los ingleses una actitud más de cobeligerantes que de aliados.

Desde la perspectiva de hoy el hecho en sí mismo es además insólito, porque nunca un ejército inglés había combatido en las tierras de la Península como amigo a su vez de portugueses y españoles durante un período de tiempo tan dilatado y excepcional, en una convivencia con los aliados harto embarazosa. Aun cuando los británicos siempre han considerado esta guerra, y así la han contado, como "su" guerra, al margen de lo que sucedió en la Península.

El nombre con el que la denominaron desde el principio, Peninsular War, tuvo, además, tal fortuna que fue utilizado poco después de su terminación por novelistas y escritores de aventuras que lo pusieron en relación con el "carácter espańol" (tal fue el caso de Alexander Dallas, adscrito al ejército británico del general Thomas Graham en el desembarco de Tarifa en febrero de 1811, en su voluminoso relato novelado que tituló Félix Álvarez or Manners in Spain, containing Descriptives Accounts of Some of the Prominent Events of the Late Peninsular War, and authentic Anecdotes Illustrative of the Spanish Character (1818) ${ }^{5}$.

5 Alexander R. C., Dallas, Felix Alvarez, or, Manners in Spain: containing descriptive accounts 
Si bien, olvidado pronto este precedente, la denominación final de "Guerra Peninsular" fue acuñada, definitivamente, tras la aparición en 1823 del primer volumen de la History of the Peninsular War de Robert Southey, un autor tan destacado en las letras británicas.

Desde entonces, éste ha sido el nombre de aquella guerra que se ha impuesto no sólo en el Reino Unido sino en todo el mundo anglosajón (aunque Napoleón siempre entendió la lucha en Portugal para expulsar a los ingleses dentro de los "asuntos de Espańa”). Y así la contaron después igualmente desde su punto de vista con olvido de tantos aspectos claves de la guerra en la Península que no le interesaban por no concernirles, con el consiguiente olvido o desprecio de aspectos fundamentales de su historia como los consistentes "en las calamidades traídas al mundo por el orgullo, la ambición, la avaricia, la venganza..., la hipocresía, la sedición o el celo desmesurado", según la famosa definición de Edmund Burke, tan obsesionado por "la perversión de la Historia" con su "exagerado estilo de insidioso panegírico"6.

De esta forma, tan limitada por consiguiente, la versión británica de "su guerra” -la Peninsular War-, transcurrió por cauces diferentes a la lucha patriótica sostenida por los españoles contra Napoleón. Los británicos no vieron que fue una guerra "nacional", que así fue como definió la guerre d'Espagne, Stendhal, como "la première guerre nationale" . Lo que hace necesario revisar la postrera versión que de ella dieron sus cronistas e historiadores posteriores. Pues difícilmente puede comprenderse aquélla si la sacamos del contexto de la guerra de España, que en este país los contemporáneos llamaron guerra de la Independencia española. Que así fue como finalmente, en el caso de España, resultó asumida desde el principio tal como se manifiesta en una muy abundante publicística contemporánea a los hechos, de la que dieron cuenta infinidad de escritos insertos en proclamas, artículos periodísticos, declaraciones y discursos.

A la vista de todo ello, con dificultad podemos entender la guerra que los británicos llevaron a cabo en la Península, si ésta la explicamos fuera del contexto de la guerra que los españoles hicieron por su cuenta, es decir, la que estos llamaron desde el principio su guerra de la Independencia. Precisamente, escribiendo desde Inglaterra en un periódico memorable, José María Blanco White, usando ya en época tan temprana el término de "guerra de la independencia española", dijo que el nervio de ésta era la "esperanza", es decir, el intento de persuadir que la mayor

of some of the prominent events of the late Peninsular War, and authentic anecdotes illustrative of the Spanish character: interspersed with poetry, original and from the Spanish. London: Printed for Baldwin, Cradock and Joy, 1818.

6 Edmund Burke, Reflections on the Revolution in France. London: J. Dodsley, 1790, pp. 209, 212 y 201

7 Stendhal, "Napoléon", en Oeuvres complètes. Paris: Champion, 1929, p. 366. 
parte de España no peleaba en vano en una tarea conjunta en la que contaba con la ayuda de Inglaterra ${ }^{8}$.

Observación ésta de gran interés que nos permite comprender que para los españoles, desde el principio, la lucha conjunta hispano-británica formó parte de una guerra por su independencia. De donde la significación simbólica para España, que no para Inglaterra, del Dos de Mayo de 1808 -"la matanza de Madrid”, la llamó Wellington-, que es mucho más que un simple episodio en las guerras napoleónicas por su extraordinaria repercusión en el enfrentamiento franco-británico. Pues se trata de una fecha emblemática que marca el inicio de la guerra, sobre la que el liberal Bartolomé Gallardo escribió que fue entonces cuando se lanzó "el primer grito de la independencia española: grito sublime que se oyó en los últimos términos de la monarquía" . Hecho que reconoció hasta el propio José Bonaparte, quien el 21 de agosto de 1810 escribió a la reina Julia diciéndole que "todos serán aquí nuestros amigos si hablamos sobre la independencia de España y la libertad de la Nación"10.

Con textos de época en la mano podríamos argumentar también que la guerra de la independencia de España fue una "guerra de independencia" para Inglaterra, que por ello luchó e hizo "su” guerra en la Península, para asegurar su independencia. El mismo Wellington llegó a decir en 1810 que si los franceses llegaran a desembarcar en Inglaterra, "entonces los súbditos de Su Majestad descubrirían lo que son las miserias de la guerra, unas miserias que gracias a la providencia no han tenido que conocer, y la prosperidad del país y la felicidad de sus habitantes quedarían destruidas" ${ }^{11}$.

Yendo más lejos en este mismo sentido un periódico británico de 1816, al año siguiente de la victoria final sobre Napoleón, la llamó "guerra de existencia" porque de ella dependió la propia "existencia de Inglaterra", que nunca dejó de estar amenazada desde que se declaró la guerra en 1793 hasta el 31 de marzo de 1814, pues "durante este largo período, apenas pasó un día en que Inglaterra no hubiese estado amenazada"12. Particularmente crítico había sido el año 1797, con la armada holandesa a disposición de Francia, las flotas británicas del norte y del canal de la Mancha amotinadas, Irlanda al borde de la rebelión, los puertos italianos controlados por Francia, y Espańa aliada a ésta. Situación que mejoró

8 "Cádiz. Sospechas contra Inglaterra", El Español, 30 de septiembre de 1811, pp. 495-504.

9 Bartolomé José Gallardo y Blanco, "Pueblo", en Diccionario crítico-burlesco del que se titula "Diccionario razonado manual para inteligencia de ciertos escritores que por equivocacion han nacido en España". Cádiz: Imprenta del Estado Mayor Genearl, 1811, p. 124.

10 Mémoires et correspandance politique et militaire du roi Joseph; publiés, annotés et mis en ordre, par A. Du Casse. Paris: Perrotin, 1853-54, vol. VII, p. 319.

11 Arthur Wellesley, duque de Wellington, Maxims and Opinions of Field-Marshal, His Grace, the Duke of Wellington. London: H. Colburn, 1845, p. 113.

12 The Courier, 19 de enero de 1816. 
sensiblemente este mismo año con la victoria del cabo de San Vicente frente a España. No obstante lo cual, el temor general a una invasión, que reforzó el sentido de unión nacional dominante, no disminuyó en verdad en Inglaterra hasta que se inició la guerra peninsular.

Un asunto controvertido, por tanto, el de su denominación que no es baladí a la hora de analizar críticamente, tal como ellos la concibieron, la guerra de los ingleses dentro de la guerra peninsular contra Napoleón. Que no en vano un autor tan cáustico y malevolente hacia los españoles como el viajero romántico británico Richard Ford, que tanto se interesó por la guerra peninsular en la versión oficial británica, llegó a ridiculizar sarcásticamente el nombre con el que se llamaba en España a la guerra. Hasta el extremo de insinuar que la guerra de los españoles más bien debiera llamarse "guerra de la Dependencia". De la dependencia, naturalmente, de España respecto de Inglaterra, que así es como en la práctica se la ha venido a considerar en el Reino Unido en su versión canónica.

Lo que nos lleva a tener que recordar que denominada, efectivamente, como guerra de la Independencia de España desde su comienzo tal como se desprende de tantos textos coetáneos, este carácter le dio una impronta especial, lo mismo que ocurrió con las guerras nacionales "de independencia" vividas por otros países en trances revolucionarios como fue el caso de los Estados Unidos en su anterior lucha con la propia Inglaterra. Aunque con la gran diferencia, señalada años después por Marx al ocuparse de ella, de que "todas las guerras de independencia libradas contra Francia llevan en común el sello de la regeneración, mezclado con la reacción, pero en ningún lado en el grado alcanzado en España”"13.

Sin embargo, entre los ingleses, el peso de la tradición -el mito- sigue siendo tan grande que, prácticamente sin excepción, los trabajos actuales dedicados a la guerra siguen ignorando la participación española. Lo mismo que ha ocurrido desde el principio. Pues las hazañas de Wellington en la Península alimentaron la imaginación de los británicos durante generaciones. La propia tradición oral con el transcurso del tiempo fue engrandeciendo y caracterizando "su" propia gesta de la que los historiadores darán una particular versión. Que así es como habrían de fundamentar la fama de invencibilidad de los ejércitos británicos que como tal se forjó en la Península. A pesar de que, como es bien sabido, hasta entonces las expediciones británicas sobre el continente, aparte de ser de muy corta duración más allá del esfuerzo bélico que significó el bloqueo, constituyeron siempre un fracaso. A lo que se suma el hecho de que, en los quince años de guerra intermitente con Francia, nunca Inglaterra pudo enviar a más de 20.000 soldados a la vez a Alemania o a los Países Bajos, los teatros de operaciones claves en la guerra continental antes de 1808.

13 Escritos sobre España. Edición de Pedro Ribas, Madrid, Ed. Trotta, 1998, p.113. 
Asimismo, dentro de su peculiar tendencia explicativa ya centenaria, los historiadores británicos al ocuparse de la Peninsular War y al tratar de "su" guerra en la Península, han minimizado un aspecto fundamental: el de la participación del pueblo español en la lucha. Cuestión fundamental que queda fuera de la lógica historiográfica británica, centrada en explicar la "gesta" de un pequeño ejército de poco más de 30.000 hombres quienes, supuestamente, serían los protagonistas de la victoria sobre el ejército napoleónico que llegó a tener desplegados en la Península hasta 300.000 soldados en enero de 1810, con el consiguiente olvido y minimización de la guerra "nacional" sostenida por sus aliados.

Nadie pone en duda que los españoles, precisamente por tratarse en buena parte de una guerra revolucionaria, lucharon en aquella empresa de forma inviable desde un punto de vista convencional. En el terreno militar lucharon de forma desorganizada y cosecharon numerosas derrotas. En medio de una conmoción revolucionaria que llegó a todos los rincones del país, la actuación de las Juntas Provinciales, que mostraron de continuo sus rivalidades con la posterior Junta Central, se levantaron ejércitos improvisados, mandados por una oficialidad inexperta, que fueron una y otra vez vencidos, pero que nunca claudicaron.

Sin embargo, a pesar de todo, la verdad fue que en los peores momentos de la lucha, en enero de 1810, con la caída de Sevilla -hasta entonces capital de la España libre frente al Madrid napoleónico- y la disolución de la Junta Central, los invasores sólo fueron dueños del terreno que ocupaban sus ejércitos. De tal manera que en ningún momento, con o sin la ayuda de Inglaterra, se quebró la resistencia. Una situación por completo diferente a lo que con anterioridad ocurrió en Italia, Austria o Prusia, que en cuestión de semanas fueron barridas por el poder napoleónico. Lo que llevó al historiador alemán Schepeler a reconocer que "el español fue el único que mantuvo una guerra mortífera de siete años"14.

Sin duda alguna la participación inglesa fue importante. Pero por sí misma no explica esta resistencia nacional, que no tiene punto de comparación en la lucha contra Napoleón en todo el continente europeo. Mientras que la acción de los británicos, que desde luego no dejaron de prestar auxilio a sus nuevos aliados en buena parte del territorio nacional, se centró en Portugal, impidiendo que este país fuese reconquistado primero por Masséna y después por Marmont. Pues incluso cuando se aventuraron más allá de la frontera portuguesa, lo hicieron siempre asegurándose de que era posible volver a la retaguardia. De tal manera que hasta 1812, cuando era evidente que la aventura napoleónica había fracasado, los aliados británicos, siempre escépticos y desconfiados de la resistencia espańola, no entraron en acción en España de forma continuada hasta cuando el camino hacia la victoria final quedó despejado. Lo cual quiere decir que también para ellos, aquélla fue una guerra de desgaste, a war of attrition.

14 Histoire de la revolution d'Espagne. Liége: J. Desoer, 1829-31, vol. I, p. 56. 
Toda una realidad que queda marginada y minusvalorada en la versión británica de la guerra peninsular, en la que sólo se tiene en cuenta la acción militar de los británicos con escasas concesiones a la guerra de los españoles. Una versión, por otra parte, en la que es frecuente que ensalcen sus heroicas hazañas en detrimento de las de los españoles con un grado de sinceridad altamente sospechoso cuando resultaba indiscutible que la victoria británica no se hubiera consumado si el enemigo común no hubiera tenido que emplear continuamente sus fuerzas para combatir a los españoles. Así que no puede sorprendernos que publicaciones recientes, algunas de ellas de muy amplia divulgación como el Everyman's Dictionary of Dates, siga definiendo la guerra de la Península como "entre Francia e Inglaterra"15.

Contando con un nivel editorial superior al de Francia y España, la publicística británica sobre la guerra en la Península alimentó la fantasía de los ingleses desde el primer momento, fabricando sus propios mitos. Así, característica común de todos los historiadores fue el olvido o la infravaloración del extraordinario esfuerzo realizado por los españoles. Hasta el extremo de que con los dedos de la mano pueden contarse los relatos en que se hace justicia a los españoles o, por lo menos, se rechaza el desprecio poco caritativo e inmerecido con que se habla de los aliados. Aun cuando no falte casi de forma excepcional algún memorialista que admita que muchas de las proezas realizadas por los españoles eran "hechos que deberían ser conocidos por mis compatriotas, y cuyo recuerdo debería entusiasmar y deleitar tanto a un soldado imparcial como a cualquier buena persona" ${ }^{16}$.

Sin embargo, no ya la publicística inmediata a la guerra, particularmente los recuerdos de los propios protagonistas, sino las historias escritas con posterioridad silenciaron esta otra cara de la moneda que, mirada desde la perspectiva de hoy, ofrece un aspecto tan vasto y espectacular del conflicto. Pues hasta un siglo después cuando Charles Oman comenzó a publicar su magna Historia de la Guerra $^{17}$-limitada a los aspectos militares-, las fuentes españoles fueron ignoradas. Actitud en buena parte condicionada por la relegación de España a una posición secundaria en el horizonte político internacional.

De esta manera todos los historiadores británicos prácticamente sin excepción se ocuparán de la Peninsular War como si se tratara de una guerra regular o estrictamente militar. Olvidarán por completo que se trató de una "guerra nacional", sin frentes, estrategias, ni reglas. Una cuestión que ha dado lugar, y continuará dándolo, a una "guerra" entre los propios historiadores españoles,

15 Everyman's Dictionary of Dates. London: Dent, 1986, p. 396.

16 Moyle Sherer, Recollections of the Peninsula, by the author of Sketches of India. London: Longman, 1825, pp. 69-70.

17 Charles Oman, A History of the Peninsular War. Oxford: Clarendon Press, 1902. 
portugueses, ingleses y franceses. Cuando hasta los historiadores locales, lo mismo que la historiografía sobre la guerra por parte de portugueses y españoles especialmente, tienen tanto que decir todavía cuando evalúan los daños sufridos por sus pueblos durante la lucha de los ingleses en Espańa.

Por no hablar de la conducta y el comportamiento de los soldados británicos, de cuya crueldad hay tantos testimonios, que constituye un área de investigación descuidada por completo en los estudios de la guerra napoleónica. Pues doscientos años después, aquellos hombres que el propio Wellington definió en 1813 ante el conde de Bathurst como la "escoria de la tierra" (no precisamente para indicar los orígenes sociales de su procedencia) constituyen un enigma por descifrar, amparados por el beneficio de la victoria final que oculta su reputación -su proverbial bravery-con el manto de la leyenda y de las medias verdades.

Ya en su tiempo el continuo desencuentro existente entre los aliados a lo largo de los seis años de lucha dio lugar a dos interpretaciones de la guerra, de carácter nacional, que tendrá muy poco en cuenta la participación del "otro" en la lucha común sobre la que pesaba la continuada desconfianza existente entre dos países que habían permanecido durante los dos siglos precedentes llenos de prejuicios y enfrentamientos. Pues mientras en sus historias de la guerra los ingleses apenas si valoran la participación española o la reducen al mínimo, hablando siempre negativamente de la Península y de sus habitantes, los españoles, por su parte, también mostraron su indignación hasta el extremo de minusvalorar la participación inglesa. Una versión ésta que sigue caracterizando la historiografía nacional de ambos países.

Lo que hace que desde el punto de vista británico esté todavía pendiente la necesidad de llevar a cabo una revisión de tantos prejuicios e inexactitudes como se han ido manteniendo a lo largo del tiempo. Porque hoy más que nunca resulta bien simplista enfocar la lucha desde un punto de vista de historia militar en sentido estricto, que es el que hasta ahora ha ocultado un cúmulo de circunstancias humanas que explican tantas cosas, y sin las cuales el conocimiento de la guerra verdaderamente no tiene sentido. Lo mismo que ha ocurrido desde el punto de vista francés a pesar de que las consecuencias de prejuicios parecidos tuvieron resultados dramáticos y catastróficos para ellos (comenzando por la misma persuasión de Napoleón de que "el pueblo español es vil y cobarde como los árabes a los que combatí en Egipto" ${ }^{18}$, que escribió a su hermano José el 9 de septiembre de 1808, y que le llevó a una aventura tan disparatada).

Las publicaciones británicas siempre han visto la guerra, además, llenas de reproches frente a la realidad espańola del momento, y zanjan el asunto describiendo las gestas militares de lord Wellington y el ejército británico con tintes tan épicos como románticos, olvidándose de todo lo demás. E ignorando a todos aquellos que tomaron parte junto con lord Wellington en las duras

18 Oeuvres de Napoleon Bonaparte. Paris: C. L. F. Panckouke, 1821, vol. V, p. 92. 
campañas contra las tropas del Imperio. Que así es como se ha construido una historiografía que hasta hace bien poco ha despreciado, especialmente por parte británica, cualquier planteamiento de carácter esencialmente militar que no sea el suyo, con el consiguiente olvido de aspectos fundamentales que los historiadores de la última generación están resaltando: la lucha por la opinión, la cultura, la vida cotidiana, el impacto de la palabra oral o la representación de la realidad, una de las nociones más ricas de la historiografía y a la vez una de las más peligrosas de manejar, por cuanto pretende comprender y hacer inteligibles los comportamientos de amplios sectores de la sociedad. De donde la ausencia de cualquier atisbo de historia sociocultural, cada vez más atractiva, que centre el interés en lo colectivo sin olvidar lo individual.

Pues, anclada en parámetros típicamente decimonónicos, la historia actual de la Peninsular War sigue ayuna de toda preocupación por ensayar la representación cultural de una sociedad, acogiendo vínculos territoriales, religiosos, generacionales y nacionales diferentes. Elementos todos ellos constituyentes de la identidad nacional, en suma, que puede aportar la misma historia de las mentalidades colectivas sin por ello olvidarse de los individuos, sus conductas, sus palabras, sus pasiones y sus vicios. En definitiva, el mundo de la sociabilidad en un espacio determinado -el peninsular-, en circunstancias excepcionales. Con su consiguiente efecto en su muy variada representación historiográfica, en el que las palabras han actuado como armas arrojadizas como si se tratara de un verdadero campo de batalla. Pues el conflicto dio lugar a una "guerra de opiniones" que ha llegado hasta nosotros.

Pendiente de una renovación, tan necesaria como urgente, la historia de la Peninsular War actualmente vigente sigue anclada en su tradicional enfoque de historia militar, que permanece ajena a cualquier intento de documentar y analizar muchas cosas fundamentales de aquella guerra: la forma de luchar de los espańoles desde la mirada del "otro" ya apuntada, la conversión de una derrota en victoria por la propaganda, como pasó con la retirada de sir John Moore, la clave del éxito de los ingleses, la forma de luchar estos en la Península, la lógica del "libertador" (Wellington), la devastación de un país o la actitud de la clase política dirigente en sus continuos enfrentamientos con las españolas, sin olvidar la nueva conciencia política que la lucha originó en los españoles.

Por si todo ello fuera poco, también hay que tener en cuenta que la historia británica de la guerra de la Península estuvo condicionada desde el principio por los intereses propagandísticos ingleses, que los utilizaron como arma política o vejatoria. Lo que nos explica que el ya mencionado hispanista "hispanófobo" Richard Ford -que tan despectivamente miraba a los españoles como "indolentes semiorientales"19- así como tantos viajeros ingleses y lectores en casa de sus obras

19 Richard Ford, A Handbook for Travellers in Spain. London: J. Murray, 1855, vol I, p. 5. 
no tuvieran reparo en hacer suya cualquiera de las malhumoradas observaciones del duque de Wellington. Como la que éste hizo el 12 de septiembre de 1812 sobre el fracaso de España, en que dijo: "Estoy realmente convencido de que no hay un solo hombre en todo el país capaz de comprender, y mucho menos aún de dirigir, cualquier gran empresa" 20 . Observación que, por el contrario, enaltecía de forma portentosa los sentimientos de grandeza del pueblo británico, mientras raramente se mostraba tendente a admitir que los españoles tuvieran su punto de razón.

Una opinión ésta demasiado frecuente en sus despachos, que aunque haya que relativizar en el conjunto de tantos textos contradictorios, sin embargo, no puede menos de dejar atónito al historiador interesado por la sociología de la guerra (por más que haya muchos otros amables y edificantes). En cualquier caso es difícil explicar que un militar y político tan reservado profiriera con tanta frecuencia juicios tan radicales y definitivos, como se advierte ya desde sus primeros despachos cuando llegó de joven a la India y vio a los indígenas como "una de las razas de hombres más falsos y malhechores", sólo superados por los musulmanes que eran "aún peores" 21.

Si bien lo importante de esta frecuente y exagerada animosidad hacia lo español está presente igualmente en las opiniones, malhumoradas también, de tantos protagonistas que participaron en la guerra. Y que, honestamente, no parece que deban silenciarse en provecho de un relato que busque la corrección histórica en detrimento de lo que, en verdad, sintieron y manifestaron los participantes directos de la guerra.

Pues así es como hay que entender testimonios tan negativos como el del capitán de dragones William Bragge que, al terminar la contienda, llegó a escribir que "no hay dos naciones más opuestas en todo que la española y la inglesa, ni dos ejércitos que se detesten mutuamente más que los de estos dos países" ${ }^{22}$. En su caso, la animosidad hacia los españoles -a quienes consideró no obstante mejores que a los portugueses- le llevó a decir incluso que "las famosas ovejas merinas deshonrarían el rebaño de cualquier gentleman inglés, y que ni las mujeres ni los hombres ni los perros ni los caballos, ni los asnos ni las mulas de este país son dignos de trasladarse a Inglaterra, donde espero no ver nada español salvo algún prisionero, un duro o un bolero"23.

20 Ford, $A$ Handbook..., vol. I, p. 139.

21 Arthur Wellesley, Duque de Wellington. Supplementary Dispatches, Correspondence, and Memoranda of Field Marshall Arthur, Duke of Wellington K.G., edited by His son, The Duke of Wellington. London: John Murray, 1858-1872, vol. I, p., 16.

22 William Bragge, Peninsular Potrait, 1811-1814. The Letters of Captain William Bragge, Third (King's Own) Dragoons. S. A. C. Cassels (ed.). Oxford, Oxford University Press, 1963, pp. $120-122$.

23 Bragge, Peninsular Portrait... 
Texto que muestra una exacerbada hostilidad política e incluso racial hacia lo español, y que es común a buena parte de la publicística británica decimonónica sobre España de la que no sólo participaron libros emblemáticos como The Bible in Spain de George Borrow o el Handbook de Richard Ford. Pues el mismo tono, determinado en gran medida por el nacionalismo británico o el fanatismo protestante, está presente salvo raras excepciones en la mayor parte de los libros publicados sobre España y, particularmente, en los dedicados a la guerra peninsular. Todo lo cual revela la existencia de un estado de opinión convencional, que venía de mucho atrás, y que conviene tener en cuenta. Lo cual, sorprendentemente, no fue óbice para que al mismo tiempo España gozara del privilegio de suscitar los más fervientes entusiasmos junto a las opiniones más hostiles, como señaló Gregorio Marañón en el prólogo a El Empecinado visto por un inglés 24 .

Cosa ante la que no cabe extrañarse, pues todo ello está presente en los Dispatches del propio Wellington que, tras su publicación, fueron tomados por la mayor parte de los ingleses como el canon de la verdad absoluta ("the TRUE ENGLISH BOOK", le llamó Ford, recurriendo a las mayúsculas para expresar su opinión ${ }^{25}$. Con la particularidad de que su autor, lejos de mantenerse en la imparcialidad a que su alta posición le obligaba, llegó hasta complacerse en abrir las viejas heridas con declaraciones sobre sus antiguos aliados cada vez más desdeñosas, llegando a contradecir sus propios partes oficiales, como han señalado algunos historiadores españoles.

Por otra parte, la tradicional visión británica de la guerra contra Napoleón en Espańa se halla condicionada por la máscara del patriotismo -el "exceso de apasionada afición a su patria" de que hablaron los historiadores decimonónicos, o el "patriotismo barato" de que han hablado algunos autores actuales- o la propaganda cuando llega a condicionar hasta el tema de la incompetencia militar que se esconde tras las batallas. Sin ni siquiera distinguir que el patriotismo es defensivo cuando expresa el amor a un país; y que el nacionalismo, en cambio, es agresivo cuando rinde culto a un pueblo y al poder de su Estado, olvidándose las más de las veces que también el pueblo tiene derecho a la verdad como tiene derecho a la vida o a la libertad.

Un hecho éste que no deja de sorprender, pues la nueva historia militar británica -no aplicada hasta ahora, sin embargo, al análisis de la Peninsular War en toda su complejidad- ha superado la vieja idea según la cual nadie que no haya experimentado de primera mano la profesión militar puede estudiarla de forma seria. Una idea que de aceptarse haría de la peste negra un coto de investigación reservado exclusivamente a los médicos, o el estudio de la reforma protestante

24 Gregorio Marañón, "Prólogo” en Frederick Hardman, El Empecinado visto por un inglés. Madrid: Castro, 1926.

25 Ford, $A$ Handbook ... vol. I, p. 81. 
a los clérigos. Que es lo que ocurre con las explicaciones generadas por una historiografía exclusivamente militar centrada en las victorias de sus regimientos y en el gran error de los españoles de exponerse a dar batallas campales de forma temeraria y harto improvisada.

Pues como ha indicado el historiador Michel Howard, en temas fundamentales de la historia militar o bien se ha hecho un "uso" indebido del pasado, o bien se ha abusado de la historia ${ }^{26}$. Una "perversión" ésta muy frecuente entre los historiadores militares del pasado. De donde la necesidad de elaborar una imagen más objetiva, mediante una cuidadosa selección e interpretación de los mismos hechos, emociones y creencias. Es decir, otra historia, una historia alternativa a la que se ha contado hasta ahora.

Sin embargo, en el caso de Inglaterra, la tradicional historia de las batallas -que la New Military History americana ha llamado con acierto "Drums and Trumpets History"-invade todavía el relato de las nuevas versiones de la guerra peninsular. Con la particularidad de que este tipo de historia tan extensamente vulgarizado no se produce solo en ambientes exclusivamente militares. Sencillamente, no es ya sólo cuestión de táctica o estrategia de la batalla sino, en mucho mayor medida, de explicación general con claves humanas fundamentales en su contextualización. Pues nadie puede poner en cuestión que cuando ha terminado por imponerse una verdad oficial, tenemos que buscar la realidad histórica a través de las reacciones a dicha propaganda oficial, que de lo contrario terminará convirtiéndose en versión canónica.

A lo que hay que añadir que las publicaciones británicas, minimizando su significado, estudian el período llenas de reproches frente a la realidad española del momento, y siempre zanjan el asunto describiendo las gestas militares de lord Wellington y el ejército británico con tintes épicos tan altisonantes al tiempo que se olvidan de todo lo demás. De la misma manera que ignoran a todos aquellos que tomaron parte junto con lord Wellington en las duras campañas contra las tropas del Imperio.

Así, sobre la base de un relato oficial profundamente acrítico, se construyó toda una mitología alrededor del "héroe" o del "genio" que lo convirtió en un personaje superior al vencido Napoleón, comparable solo a Alejandro, a Aníbal (Francis Meredyth lo llamó el "Escipión de Britania" o a César. Algunos tratadistas mostraron su desacuerdo cuando le compararon con el general romano Quinto Fabio Máximo (que recibió el sobrenombre de Cunctator, "el que retrasa", en referencia a su táctica militar durante la segunda guerra púnica, que llamaron "tácticas fabianas"). 
El culto a su memoria fue tan grande que no hay ciudad en el Reino Unido en donde no haya numerosos edificios, plazas, calles, monumentos, escuelas, instituciones, iglesias, tiendas y pubs que no lleven el nombre del héroe invicto. Hasta los restaurantes siguen sirviendo los Beef Wellington. Todo lo cual no deja de dar una idea de hasta qué punto la "fabricación" del personaje ha impregnado y sigue estando presente en la cultura británica. Incluso en las naciones del continente se le presentó como el salvador de Europa.

Aun cuando, paradójicamente, no pocos aspectos de los entresijos de la alianza hispano-británica durante la guerra peninsular continúan siendo en gran medida una cuestión historiográfica a resolver. Pues la realidad es que muchas son las cuestiones que pueden ser objeto de debate, desde la fidelidad por ambas partes hasta cómo los ingleses utilizaron los subsidios para doblegar el gobierno español, pasando por la forma como se luchó o el monto de la ayuda económica y militar. Cuestiones todas tan complejas que, ante la magnitud de una guerra como aquélla, no pueden concluirse aceptando la tesis simplista de que la derrota final de Napoleón se debió a la capacidad financiera de los ingleses.

La misma relación entre los aliados sigue presentando hoy las mismas aristas y dificultades entre los protagonistas de entonces que entre los historiadores actuales. Y lo mismo por parte española que por parte inglesa, aun cuando la labor de historiar aquella alianza se encuentra todavía en no pocos aspectos por hacer. Hay demasiada simplificación y demasiado peso de la tradición historiográfica. Ya que el análisis de la presencia británica en la Península no puede entenderse desde un ángulo exclusivamente militar, ofrecido bien por la versión oficial británica de los hechos o por la española.

Una característica historiográfica de esta particular guerra británica sigue presentando, además, un tinte antiespañolista visceral y bastante primitivo, en el que continuamente se convierte a los dirigentes políticos y militares españoles de la época en chivos expiatorios de las desgracias comunes aliadas. Su ensañamiento, por ejemplo, con el teniente general español Gregorio González de la Cuesta que como tantos otros militares consideraba peligrosa la actitud independiente de las juntas provinciales-, al que se tilda continuamente de ineficaz, inepto, arrogante, llega a los límites de la paranoia. En tales relatos se percibe, además, un sello de resentimiento latente que a los ojos de la razón no se explica más que dentro del contexto señalado.

Por otra parte, siendo tan extensa la masa documental que existe sobre la guerra, no sólo los historiadores sino el gran público interesado en el tema $-y$ este tema ha interesado y sigue interesando a los británicos de forma casi obsesiva junto con los otros asuntos inefables de la Gran Armada o Trafalgar- siguen prefiriendo la versión canónica de Napier (1828), que es el punto de partida de esta forma de entender la Peninsular War en buena parte del mundo anglosajón. Aún cuando el citado historiador reconoce que "antes de que la Península probara 
su excelencia, las tropas inglesas fueron desprestigiadas de la manera más absurda en países extranjeros, y en su mismo país eran despreciadas" 27 .

No obstante, su influencia ha sido tan determinante que el recientemente fallecido historiador británico John Keegan, que tanto ha contribuido a modificar los presupuestos de la vieja historia militar, ha puesto en cuestión alguna de las descripciones de Napier. Sin embargo, tras subrayar su carácter mítico y falta evidente de verosimilitud "en un momento generalmente reconocido como uno de los culminantes del esfuerzo británico en las guerras contra Napoleón", tuvo que justificarlo por el hecho de haber sido "un pionero", reconociendo irónicamente que "estoy siendo injusto"28.

Pues según nos dice el citado historiador, Napier "tuvo para los ingleses de su época el mismo carácter de épica nacional que tendría para los de cinco generaciones después la lucha contra Hitler" ${ }^{29}$. No en vano fue el modelo que siguió T. E. Lawrence para contarlo en Los siete pilares de la sabiduría (1922). La Enciclopedia Británica en su novena edición llegó a equiparar a Napier con Tucídides y César. Todo lo cual no puede dejar de extrañarnos, pues todavía un siglo después de su publicación, uno de los decanos de los historiadores académicos ingleses llegará a calificar la tendenciosa obra de aquél como "la mejor historia militar en inglés y quizás en cualquier idioma" ${ }^{30}$. A pesar de que un crítico contemporáneo suyo muy perceptivo ya le acusó de "sacrificar todas las cosas menores y aparentemente insignificantes al gran efecto general" ${ }^{1}$. No obstante, su libro llegó a ser el origen del interés de numerosos ingleses por los asuntos españoles.

Tampoco los ingleses supieron apreciar particularmente el carácter de la guerra revolucionaria, patente en la guerra de guerrillas, a las que se debieron según el novelista español Galdós tanto la "permanencia nacional" como "el respeto que todavía infunde a los extranjeros el nombre de España” (en especial, esa "seguridad vanagloriosa, pero justa, que durante medio siglo hemos tenido de que nadie se atreverá a meterse con nosotros") ${ }^{32}$. La referencia a Galdós es obligada porque, como hoy se reconoce, sus narraciones al igual que las de Balzac, Dickens o Tolstoi, lograron el grado de plenitud, de penetración en el mundo y verdad característico de las obras maestras.

27 W. F. P. Napier, History of the War in the Peninsula and the South of France, from the Year 1807 to the Year 1814. London: John Murray, 1828-1840, vol. I, p. 10.

28 John Keegan, The Face Of Battle: A Study of Agincourt, Waterloo and the Somme. London: Random House, 2011, p. 40.

29 Keegan, The Face Of Battle..., p. 40.

30 John Ramsay McCulloch, A Catalogue of Books, the Property of a Political Economist; with Critical and Bibliographical Notices, London, 1862, p. 261.

31 Keegan, The Face of Battle... p. 41.

32 Benito Pérez Galdós, Juan Martín el Empecinado [Episodios Nacionales, $1^{a}$ serie]. Madrid: Imprenta de Noguera, 1874, pp. 59-60. 
Sin embargo, como aliados de los españoles, los ingleses sí entendieron la guerra en términos de colaboración, pero sin comprender que en una guerra total como aquélla se hacía muy difícil la lucha convencional. De donde el desprecio a un tipo de lucha que, no obstante sus limitaciones, tuvo y ejerció un desgaste inusitado en la guerra contra Napoleón. Pues ante una guerra como aquélla, ¿cómo podía juzgarse de forma convencional la actuación de las autoridades sin plan ni concierto o la forma de combatir de unos ejércitos que, caso insólito en la guerra napoleónica europea, destrozados una y otra vez, volvían a pelear de forma aparentemente inexplicable?

Muy pronto en Londres la versión británica que los ingleses dieron de "su" guerra exasperó a los liberales espańoles que se encontraban refugiados en la propia Inglaterra, escandalizados ante lo que se decía de su país y de los españoles. Hasta el punto de que José Canga Argüelles, profundamente indignado ante tantas arbitrariedades como se escribían (como la de que "muchos forman juicio de España por lo acaecido en Zaragoza como si su espíritu hubiera sido común a la nación" $\left.{ }^{33}\right)$, cogió la pluma para rechazar tamaños improperios. Que así fue como, en 1829, en su exilio de Londres y en español, publicó sus Observaciones sobre la historia de la Guerra de España que escribieron los Sres. Clarke, Southey, Londonderry y Napier, una obra reivindicativa, que se reimprimió en Madrid justo a partir de 1833 , en la que frente a tantas "inexactitudes y falsedades" de los ingleses puso en entredicho el protagonismo y el papel de sus ejércitos en la lucha ${ }^{34}$.

A la altura de aquella fecha, el autor español mostraba su indignación por el "caprichoso y calculado tesón" con el que se escarnecía a los españoles, cuando "célebres militares ingleses en 1814 nos consideraban dignos de la inmortalidad, por el valor y la firmeza que habíamos desplegado en los conflictos más terribles" 35 (el caso de lord Bentinck en su proclama a los italianos de 14 de marzo de 1814). Sobre todo cuando se contaba todavía "con el testimonio respetable de muchos testigos de las hazañas que hoy nos disputan, y de la constancia que se nos niega...". Pues, según el español, "para confusión de los detractores..., contamos con el dictamen de afamados militares británicos que elogiaron nuestra decisión y nuestro valor" 36 .

En el mismo año de su publicación, el marqués de las Amarillas - uno de los pocos generales españoles que hablaban inglés, y que conoció de cerca a Wellington con quien luchó en Vitoria- escribió desde Sevilla a Washington Irving diciéndole que la obra del coronel Napier "en la parte que concierne a los españoles sería

33 Canga Argüelles, Observaciones..., p. 105.

34 José Canga Argüelles, Observaciones sobre la historia de la Guerra de España : que escribieron los señores Clarke, Southey, Londonerry y Napier publicadas en Londres el año de 1829. Madrid,

Imprenta de Miguel de Burgos 1833-1836.

35 Canga Argüelles, Observaciones..., p. 6.

36 Canga Argüelles, Observaciones..., p. 10. 
menester hacerla de nuevo, porque hay en ella demasiadas inexactitudes". En su opinión, la obra del inglés no era una historia "escrita con el objeto de transmitir a la posteridad la narración verdadera de los hechos, sino la demostración de una proposición que sienta en sus primeros renglones" ${ }^{37}$. Es decir, que la liberación de la Península no fue cosa de los españoles sino de los ingleses. Ante su amigo americano, el general español se quejaba de que el historiador inglés escribiera "constantemente de una manera hostil a los españoles", adoptando "todas las vulgaridades y todas las equivocaciones que han podido llegar a sus oídos". En su opinión, su historia no se arreglaba poniéndole notas, sino que era necesario escribir "otra historia" 38 .

Lo mismo que pensaba Antonio Alcalá Galiano, que tan bien llegó a conocer a los ingleses durante el tiempo que pasó en Inglaterra como emigrado liberal, que igualmente mostró su disconformidad con las nuevas Historias inglesas sobre la guerra peninsular como la de Southey y, en particular, la de Napier. "No aventuramos gran cosa en decir que no puede satisfacer a un lector imparcial, juicioso y enterado de las cosas de España, ni una ni otra historia", escribió. La primera, en su opinión, "por el odio ciego del escritor a los franceses", y la segunda "por un odio no menos ciego a los españoles y a su causa", pues, en su opinión, aparte de en otros aspectos equivocados, ambos historiadores británicos coincidían en mirar el levantamiento del pueblo español como antirrevolucionario, encaminado a sostener el poder absoluto y los abusos de la aristocracia civil y religiosa, al tiempo que incurrieron en todo tipo de "preocupaciones vulgares" 39 .

Así lo vio, igualmente, el general español Miguel Ricardo de Álava -tan próximo a Wellington que hasta llegó a vivir en su propia casa de Londres-, que lo conocía bien y lo admiraba como historiador, aunque declaró que estaba enfadado con él porque había sido un "canalla" con los españoles. Algo que al británico no debió de preocuparle gran cosa porque él era el primero en ser consciente de que su obra estaba llena de "todo tipo de mentiras" 40 .

Argumentos atávicos característicos de una vieja historia que por mucho que nos extrańe actualmente sigue conformando por entero la "nueva", aun cuando ésta trate de adoptar un lenguaje políticamente más correcto, si bien en el fondo continúa siendo impermeable a las reglas imprescindibles de la historia, the

37 En José Canga Argüelles, Documentos pertenecientes..., p. 357.

38 "Carta del Excmo. Sr. Marqués de las Amarillas al Sr. Irving sobre el juicio que merece la Historia del Sr. Napier", en José Canga Argüelles, Documentos pertenecientes a las Observaciones sobre la Historia de la Guerra que escribe en ingles el teniente coronel Napier. Madrid: Imprenta de Don Marcelino Calero, 1836, vol. II, pp. 357-358.

39 Antonio Alcalá Galiano, Obras escogidas [Biblioteca de Autores Españoles], Madrid: Atlas, 1955, p. 447.

40 Priscilla Napier, Revolution and the Napier Brothers, London: Michael Joseph, 1973, 132136 
practice of history, de la que se ocupó el historiador británico Geoffrey Elton. Pues nos encontramos ante un tipo de historia que no experimenta la más mínima duda frente a lo sucedido en el pasado y a la forma de contarlo por parte de los nuevos historiadores, que no cuestionan la parcialidad de los relatos ni someten la narración a los principios más elementales de la crítica.

Sobre todo cuando tantos de sus planteamientos, rayanos en los límites de la verosimilitud, resultan en buena lógica histórica inaceptables. Máxime cuando difícilmente se avienen con la tarea de comprender la existencia de los otros, especialmente cuando se hace historia de otro país que en su mayor parte, con la propia población incluida, permaneció siendo para ellos una terra incognita (en el fondo para el propio Wellington, España no dejó de ser sino "ce diable de pays, où j'ai fait la guerre pendant cinq ans", tal como le confesó a su amigo el general Dumouriez $)^{41}$.

En el caso de la Peninsular War el poder organizador de los relatos canónicos oculta muchos hechos importantes que se encuentran fácilmente a nuestro alcance, aparte de tergiversar o interpretar erróneamente la información que ha quedado registrada. Con lo que la fascinación de los relatos oficiales, presentados a veces como primarios, se convierte en un serio obstáculo que impide la comprensión de la realidad histórica que en verdad sigue permaneciendo oculta. De aquí la necesidad de plantearnos a dos siglos de distancia de los acontecimientos numerosos aspectos viciados por una historiografía que, construida sobre bases discutibles, exige una revisión a fondo de no pocas de sus tesis, más allá de la magnificación de la superioridad y protagonismo británico y la subordinación de españoles y portugueses a su gesta bélica.

Sin embargo, este panorama es muy distinto si se contempla desde lejos y con independencia de los planteamientos culturales y nacionales señalados, tan cargados de prejuicios, lo mismo en Inglaterra que en España. Es el caso, por ejemplo, de la historiografía napoleónica rusa que apenas si ha resaltado la gesta británica en la Península mientras, por el contrario, ha valorado tanto la lucha de los españoles. El ejemplo más sobresaliente es el del historiador Albert Manfred, tan apreciado por los historiadores napoleónicos occidentales, quien tras resaltar el coraje y heroísmo de los españoles, ha considerado la "pequeña guerra" realizada por aquellos como mucho "más terrible que las batallas en campo raso". Según su tesis, fue el pueblo la fuerza fundamental que quebró el poder militar del Imperio y puso fin a la dominación francesa. Asimismo, este historiador, tras desmitificar la acción británica, hasta dice de Wellington que "no era el genio militar que se

41 Arthur Wellesley, Duque de Wellington, The Dispatches During His Various Campaigns in India, Denmark, Portugal, Spain, the Low Countries and France from 1799 to 1818; Compiled from Official and Authentic Documents by John Gurwood. London: Murray, 1838, p. 309. 
dijo más tarde", en lo cual sigue la opinión de Marx, que "le consideró con toda razón como el hombre de la mediocridad".

Pero como quiera que fuera, en la construcción historiográfica la imagen británica se consolidó progresivamente hasta construir todo un paradigma iconográfico e interpretativo-mítico-que habrá de convertirse en un componente esencial de una tradición inventada. De donde la necesidad de analizar toda una representación del pasado que en tantas ocasiones difiere de la realidad histórica. Asunto del que se ocupó ampliamente el historiador británico Hobsbawm, cuando, al estudiar la cuestión capital de la "invención de la tradición” ‘2, llegó a la conclusión de que todos los historiadores, sean cuales sean sus objetivos, están comprometidos en un proceso similar en tanto que contribuyen de forma más o menos consciente no sólo a la creación, desmantelamiento o reestructuración de las imágenes del pasado que no sólo pertenecen al mundo de la investigación especializada, sino a la esfera pública del hombre. 